\title{
Effect of Business Incubator Services on Performance of Business Ventures at Nairobi Incubation Lab, Kenya
}

\author{
Dorcas Njoki Mungai ${ }^{1}$, Dr. Agnes Njeru ${ }^{2}$ \\ ${ }^{1,2}$ Entrepreneurship and Procurement, Jomo Kenyatta University of Agriculture and Technology, P.O.BOX, 62000, Nairobi, 00200, Kenya
}

\begin{abstract}
This study aimed to examining the effect of business incubation services on performance of businesses ventures at Nairobi Incubation Lab (NaiLab), Kenya. The study employed correlation research design. The population of study encompassed all business ventures at Nairobi Incubation Lab (NaiLab). Data was collected by use of structured questionnaires that were issued by the researcher and collected later for analysis. Both descriptive and inferential statistics were used. Descriptive analysis such as mean, frequencies and standard deviation were used to describe the independent and dependent variable while inferential analysis (correlation analysis) were used to test the relationship between business incubation services and performance of business ventures at different stages of incubation. Hypothesis testing was also carried out using one way ANOVA. The major findings of the study are that physical infrastructure, Networking, business management and positively correlated with performance of business ventures. The study concludes that business incubation services should be provided in variety to improve business performance.
\end{abstract}

Keywords: Business Incubation, Business Incubator, Performance, Nairobi Incubation Lab

\section{Introduction}

Starts up businesses in Kenya have been facing a number of challenges in the wider business environment. Recent studies in Kenya have shown that only two-thirds of start ups survive the first two years and less than half of them make it to four years.With this numbers, many would be entrepreneurs think twice before taking the plunge. Business incubation has been identified as a strategy and process for reducing the failure rates of new start- ups world over and Kenya in particular. Business incubators provide a number of services whose lack is associated with massive business failures. A number of scholars have done studies on impact of business incubation services on performance of business word over but gaps still exist in literature. There is no research to ascertain importance of incubation services on success of business ventures at different stages of incubation process in Kenya. This study therefore focused in evaluating the effect of various business incubation services on the performance of business ventures at Nairobi Incubation Lab, Kenya.

\subsection{Objectives of the Study}

The study intended to establish the effect of incubation services on performance of business ventures at Nairobi Incubation Lab (NaiLab), Kenya. From the general objective, the following specific objectives can be drawn,

1) To establish the effect of incubator physical infrastructure on performance of business ventures at NaiLab.

2)To determine the effect of incubator networking on performance of business ventures at NaiLab.

3) To examine the effect of business management advice on performance of business ventures at NaiLab.

4) To identify the effect of incubator financial support on performance of business ventures at NaiLab.

\subsection{Significance of the Study}

This study aims to build literature that will stimulate further research on business Incubation and Its contribution to performance of businesses. The findings and recommendations of the completed study will enable the management of NaiLab business incubator to fine-tuning its program to fit and benefit business ventures at different stages of incubation. Scholars and

\section{Literature Review}

The following section reviews literature that is related to effect of business incubation services on performance of business ventures. The review shows the gaps that the current study aimed at filling.

\subsection{Empirical Review}

\subsubsection{Physical Infrastructure Services}

Incubates are provided with well-furnished offices that come services, including, Reception services, Shared meeting rooms, dedicated internet access and Business centre services (Hurley, 2002). Incubators optimize use of common space to foster informal networking among companies. Hackett \& Dilts (2004) holds that business incubator seeks to provide its incubatees with a strategic, value-adding intervention system of monitoring and business assistance.

The relevance of the shared localities by incubator is also pointed out by Bruneel et al., (2012) emphasizing on the opportunities for knowledge transfer and experience sharing between the Incubatees. This physical infrastructure like offices offers economies of scales that results in reduced overhead costs; it also takes the need to manage these daily non-core activities away from the start-ups, allowing them to concentrate on the development of their business (Bruneel et 


\section{International Journal of Science and Research (IJSR) \\ ISSN (Online): 2319-7064}

Index Copernicus Value (2013): 6.14 | Impact Factor (2015): 6.391

al., 2012). Most researchers consider Infrastructure to be having little impact in developing the tenant capabilities, although it supports tenant survival and minimizes the challenges associated with the practical side of start-ups and makes the tenants focus quickly on their business (Rice, 2002).

\subsubsection{Business Management Advice Services}

Management advice involves helping incubates gain experience from successful entrepreneurs. It involves providing access to first-class business expertise, providing business consulting services when needed for specific problems, providing professional mentoring to help a company identify its problems and develop solutions, providing improvements of a company's business plan, providing coaching on business presentations to potential customers, financiers and venture capital firms (Chinsomboon, 2000 and Lalkaka \& Abetti, 1999). Such services are aimed at reducing the start-up's costs. Relating to business support, incubators' success is defined according to the success and expansion of the new businesses, namely their sustainability after the incubation period. Business management advice includes the provision of professional services such as accounting, legal advice for incorporation and taxation issues and formulating ownership and employee option plan structures (Bollingtoft \& Ulhoi, ,2005)

\subsubsection{Financial Services}

Bollingtoft \& Ulhoi, (2005) reports that financial models for incubation revolve around rental and external services, subsidies, sponsorships, and deferred revenue. Financial support involves providing small-scale seed capital funds, Building networks of contacts and partners in the financial sector, providing the start-ups with advice on how to seek Angel capital financing and Venture capital financing. (Chinsomboon, 2000). To be profitable, or even be simply self-sustainable, business incubators should carefully design a revenue generation model containing more than one source, or stream, of revenue. Lalkaka \& Abetti (1999) hold that high technology entrepreneurs usually have more financing difficulties because start-up funds must be raised for several years of technology development before a product is ready for the market. Formal and informal venture capitals are complementary sources of funding for high tech new ventures. The access to Venture Capital Firms will encourage the growth of high-tech firms and will act as a catalyst for the creation of new products and services.

\subsubsection{Networking Services}

According to Brooks, (1986), Networking involves encouraging business relationships to develop, Helps informal cross-fertilization of ideas, Helps entrepreneurs overcome the sense of isolation, and Helps lobbying for better business environment .Incubators may engage in network mediation with the purpose of compensating for the incubatees' lack of established entrepreneurial networks (Peters et al., 2004). Mediation networks may provide information, knowledge and expertise that are vital for the survival of new ventures and may also reduce the uncertainty they experience (Collinson \& Gregson, 2003). Networks can emerge between incubatees and external actors, such as potential customers, partners, employees, university researchers and financiers (Bollingtoft \& Ulhoi, 2005;

Clarysse et al., 2005; Hackett \& Dilts, 2004).

\subsection{Conceptual Framework}

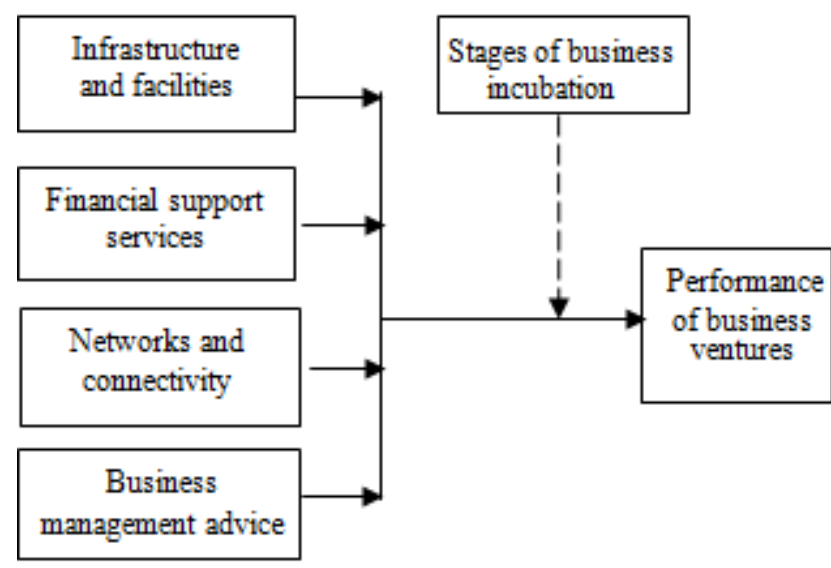

Figure 1: Conceptual Framework diagram

\section{Research Methodology}

\subsection{Research Design}

This study adopted correlation research design that was qualitative and quantitative in nature. Correlation enabled researcher to establish the relationship between business incubator services and performance of business ventures at different stages of incubation process in Kenya (Cooper \& Schindler, 2006). The study targeted Population includes all in-house- incubates and graduated business incubates at NaiLab and the current staff of NaiLab. A total number of 120 people were targeted that included in-house incubates; graduated business incubates and staff of NaiLab (Mugenda \& Mugenda, 2003)

\subsection{Sampling}

Stratified sampling was employed where target population was categorized into in-house incubates, graduated entrepreneurs and staff of business incubators. The following formula developed by Yamane (1967) was used to establish sample size. $\quad n=\mathrm{N} /\left(1+\mathrm{N}\left(\mathrm{e}^{2}\right)\right)$

Where; $\mathrm{n}=$ the desired sample size

$\mathrm{e}=$ probability of error (i.e., the desired precision, e.g., 0.05 for $95 \%$ confidence level).

$\mathrm{N}=$ the estimate of the population size

This generated a sample size of 92 respondents comprising the incubatees, graduated entrepreneurs and the NaiLab staff. This sample size was be distributed based on proportions in the target population identified by stratified random sampling .The researcher then used simple random sampling to actually select 92 respondents to participate in the study from the various strata in the target population.

\subsection{Data Analysis}

The collected data collected by use of closed ended questioners inform of likert scale was first checked for completeness and comprehensibility. The data was then 


\section{International Journal of Science and Research (IJSR) \\ ISSN (Online): 2319-7064}

Index Copernicus Value (2013): 6.14 $\mid$ Impact Factor (2015): 6.391

coded and analyzed using the SPSS version 20. Both descriptive and inferential statistics were used to analyse data collected. For descriptive statistical analysis, means, frequencies, percentages and standard deviations were calculated. And for inferential statistics, a correlation analysis was conducted to test the relationship between business incubator services and performance of business ventures by calculating Pearson's correlation coefficient at 95\% level of significance. Hypotheses testing were also carried out using one way ANOVA.The results were presented using tables with their associated interpretations.

\section{Results and Discussion}

\subsection{Correlation Analysis}

In this subsection the correlation analysis using the Pearson Product Moment Correlation was carried out to determine the degree of bivariate correlation between the variables of the study to show the degree of their association between independent and dependent variable .The resulting correlation matrix given in Table 1.

Table 1: Bivariate correlation analysis

\begin{tabular}{|c|c|c|c|c|c|c|c|}
\hline & PIS & NS & BMS & FS & & PBV \\
\hline \multirow[t]{3}{*}{ PIS } & Pearson Correlation & 1 & $.598^{* *}$ & $.519^{* *}$ & $.540^{* *}$ & .45 & \\
\hline & Sig. (2-tailed) & & .000 & .000 & .000 & .00 & \\
\hline & $\mathrm{N}$ & 66 & 66 & 66 & 66 & 66 & \\
\hline \multirow[t]{3}{*}{ NS } & Pearson Correlation & $.598^{* *}$ & 1 & $.386^{* *}$ & $.460^{* *}$ & .40 & \\
\hline & Sig. (2-tailed) & .000 & & .001 & .000 & .00 & \\
\hline & 3 & 66 & 66 & 66 & 66 & 66 & \\
\hline \multirow[t]{3}{*}{ BMS } & Pearson Correlation & $.519^{* *}$ & $.386^{* *}$ & 1 & $.455^{* * *}$ & .30 & \\
\hline & Sig. (2-tailed) & .000 & .001 & 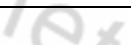 & .000 & .01 & \\
\hline & $\mathrm{N}$ & 66 & 66 & 66 & 66 & 66 & \\
\hline \multirow[t]{3}{*}{ FS } & Pearson Correlation & $.540^{* * *}$ & $.460^{* *}$ & $.455^{* *}$ & 1 & .54 & \\
\hline & Sig. (2-tailed) & .000 & .000 & .000 & & .00 & \\
\hline & $\mathrm{N}$ & 66 & 66 & 66 & 66 & 66 & \\
\hline \multirow[t]{3}{*}{ PBV } & Pearson Correlation & $.456^{* *}$ & $.409^{* *}$ & $.308^{*}$ & $.543^{* *}$ & 1 & \\
\hline & Sig. (2-tailed) & .000 & .001 & .012 & .000 & & \\
\hline & $\mathrm{N}$ & $66 \div$ & 66 & 66 & 66 & 66 & \\
\hline \multicolumn{8}{|c|}{$* *$. Correlation is significant at the 0.01 level (2-tailed). } \\
\hline \multicolumn{8}{|c|}{$\begin{array}{l}\text { *. Correlation is significant at the } 0.05 \text { level (2-tailed). } \\
\text { Independent variables: physical infrastructure services (PIS),Networking services (NS),Business } \\
\text { management services(BMS) and financial services (FS) } \\
\text { Dependent variable: performance of business ventures(PBV) }\end{array}$} \\
\hline
\end{tabular}

The results in Table 1 show the persons correlation between Business incubation services variables and performance of business ventures at NaiLab, Nairobi Kenya. Physical infrustructure was moderately significant positively correlated with performance of business ventures at NaiLab $(\mathrm{r}=0.456, \mathrm{p}=0.000, \alpha=0.01)$. Networking services was also significant and moderately positively correlated with the performance of business venture $(r=0.409, p=0.001, \alpha=$ 0.01 ). business management servises was significant and positively correlated with performance of business ventures at NaiLab $(\mathrm{r}=0.308, \quad \mathrm{p}=0.012, \alpha=0.01)$ but the relationship was not significant at $(1 \%)$. Financial services was significant and positively correlated with performance of business ventures $(r=0.543, p=0.000, \alpha=0.01)$. Findings show that Physical infrustructure was moderately positively correlated with performance of business ventures at NaiLab ,this moderate correlation means that when the incubator management improves the physical infrastructure at NaiLab, The performance of the incubatees venture businesses improved in terms of performance indicators like survival, job creation, growth in profits and sales. The moderate correlation could be attributed to the fact that NaiLab incubator specializes in incubating technology oriented business ideas that relies much on virtual platform with incubator. The virtually connected incubatees do not have much need for physical infrastructure lie office space and rooms

Networking services was also moderately positively correlated with the performance of business venture. The positive relationship means that when the incubator improves the level of networking for the incubatees for instance with

Prospective customers and financial institutions, the performance of business ventures owned by incubatees improved since their customers based improved as well as access to needed finances from financial institutions However the relationship is moderate since some respondents held contrary opinion that the networking services provided by NaiLab were not did not improve the performance of their ventures. This could be attributed to the fact that some networking services was not well provided for instance statement that NaiLab organises international trade fairs was not supported by most respondents.

Results also reveal that business management servises was weakly positively correlated with performance of business ventures at NaiLab. The positive correlations means that when NaiLab improved its business advice to the incubatees on how to run their business ventures, their performance improved in terms of performance indicators like growth in 


\section{International Journal of Science and Research (IJSR) \\ ISSN (Online): 2319-7064}

Index Copernicus Value (2013): 6.14 | Impact Factor (2015): 6.391

profits, survival and growth and expansion. The management should consider improving level of business advice to incubatees to improve their ventures. However the correlation was weak, this could be attributed to some business management advice services that were not satisfactorily offered. For instance most respondents did not support statement that NaiLab offers book keeping, Marketing and counselling services hence the weak correlation. Finally, financial services was relatively strongly correlated with performance of business ventures as compared to other services offered at NaiLab .The positive correlation means that when NaiLab management improved access to financial services for the benefit of incubatees businesses, the level of the performance of the business ventures improved greatly. The management should thus consider improving the mix of financial services it offers to incubatees to improve the performance of their business. The correlation was relatively stronger compared to other business incubation services (infrastructure, networking and business management advice).This means that financial services is the most important service that the performance of incubatees business hinges on at NaiLab.

\subsection{Hypotheses Testing}

The hypotheses were tested using one-way ANOVA to establish the association between dependent variable and independent variables at 0.95 level of significance using Ftest.

$H_{a} 1$ : Access to incubator infrastructure has a significant effect on performance of business ventures at NaiLab.

The researcher tested the association between dependent variable performance of business ventures and independent variable physical infrastructure as shown in table 2 .

Table 2: One-way ANOVA Performance of Business venture by Physical Infrastructure Services

\begin{tabular}{|c|c|c|c|c|c|}
\hline & $\begin{array}{c}\text { Sum of } \\
\text { Squares }\end{array}$ & Df & $\begin{array}{c}\text { Mean } \\
\text { Square }\end{array}$ & F & Sig. \\
\hline Between Groups & 1.346 & 13 & .104 & 1.690 & .091 \\
\hline Within Groups & 3.186 & 52 & .061 & & \\
\hline Total & 4.532 & 65 & & & \\
\hline
\end{tabular}

According to table 2 the significance was 0.091 with an $\mathrm{F}$ value of 1.699. The level of significance was higher than 0.05 and this means that physical infrastructure do not show statistically significant relationship with performance of business ventures in NaiLab. Therefore this study rejects the alternative hypothesis and concludes that there is no statistical relationship between physical infrastructure and performance of business ventures at NaiLab. This study finds no significant association between infrastructure and performance of business ventures admitted in NaiLab. This insignificant association may be attributed to the fact that in NaiLab incubator specializes in incubating technology oriented business ideas that relies much on virtual platform with incubator. The virtually connected incubatees do not have much need for physical infrastructure lie office space and rooms hence the insignificant association. The finding is in disagreement with results of study by Allen (1988); Sherman and Chappell (1998) who established that the level of incubator development has a strong positive association with the performance of incubatee businesses terms of survival and job creation. It is therefore very necessary that the incubator should provide right mix of infrastructural facilities to ensure success of incubatees' business ventures in terms of survival, growth and job creation.

$\mathrm{H}_{\mathrm{a}}$ 2: Access to Networking services has a significant effect on performance of business ventures at NaiLab.

The researcher tested the association between dependent variable performance of business ventures and independent variable networking services as shown in table 3.

Table 3: One-way ANOVA performance of business venture by networking services

\begin{tabular}{|l|r|c|c|c|c|}
\hline & $\begin{array}{c}\text { Sum of } \\
\text { Squares }\end{array}$ & Df & $\begin{array}{c}\text { Mean } \\
\text { Square }\end{array}$ & F & Sig. \\
\hline Between Groups & 1.215 & 10 & .121 & 2.014 & .049 \\
\hline Within Groups & 3.317 & 55 & .060 & & \\
\hline Total & 4.532 & 65 & & & \\
\hline
\end{tabular}

According to table 3, the significance was 0.049 with an $\mathrm{F}$ value of 2.014. The level of significance was lower than 0.05 and this means that networking services do show statistically significant relationship with performance of business ventures in NaiLab. Therefore this study accepts the alternative hypothesis and concludes that there is a significant statistical relationship between networking services and performance of business ventures at NaiLab.

This finding is in agreement with finding by Lichtenstein, (1992) that holds that internal incubator network formation as strong significant association with incubatee success and finding by Hansen et al., (2000) who posited that incubatorindustry network and incubator support services network density have a strong association with business success .Given the agreement by other researchers on the strong association between incubator networking and performance of incubates business, it is evident that incubator networking is very paramount in success of business ventures in an incubator.

$H_{a}$ 3: Access to incubator business management advice has a significant effect on performance of business ventures at NaiLab.

The researcher also tested the association between dependent variable performance of business ventures and independent variable business management services as depicted in table 4 .

Table 4: One-way ANOVA performance of business venture by business management services

\begin{tabular}{|c|c|c|c|c|c|}
\hline & $\begin{array}{c}\text { Sum of } \\
\text { Squares }\end{array}$ & Df & $\begin{array}{c}\text { Mean } \\
\text { Square }\end{array}$ & F & Sig. \\
\hline Between Groups & 1.504 & 15 & .100 & 1.656 & .042 \\
\hline Within Groups & 3.028 & 50 & .061 & & \\
\hline Total & 4.532 & 65 & & & \\
\hline
\end{tabular}

According to table 4 , the significance was 0.042 with an $\mathrm{F}$ value of 1.656. The level of significance was lower than 0.05

and this means that business management advises provided at NaiLab do show statistically significant relationship with 


\section{International Journal of Science and Research (IJSR) \\ ISSN (Online): 2319-7064}

Index Copernicus Value (2013): 6.14 | Impact Factor (2015): 6.391

performance of business ventures in NaiLab. Therefore this study accepts the alternative hypothesis and concludes that there is significant statistical relationship between business management services and performance of business ventures at NaiLab.

This finding is in agreement with findings by a numbers of researchers (Autio \& Kloftsen, 1998; Rice, 2002 and Sherman, 1999) who also found strong positive association between survival of incubatee businesses and incubator manager-incubatee relationships which are an aspect of business management advice inform of counseling and mentorship. Given this strong positive association, managers of business incubators should enrich the level of interaction with incubatees to improve the incubator manager -incubatee relationship in an effort to improve the survival of incubatee businesses.

$\mathrm{H}_{\mathrm{a}} 4$ : Access to incubator financial support has a significant effect on performance of business ventures at NaiLab.

The researcher also tested the association between dependent variable performance of business ventures and independent variable financial services as depicted in table 5

Table 5: One-way ANOVA performance of business venture by financial services

\begin{tabular}{|l|r|r|r|r|r|}
\hline & $\begin{array}{c}\text { Sum of } \\
\text { Squares }\end{array}$ & Df & $\begin{array}{c}\text { Mean } \\
\text { Square }\end{array}$ & $F$ & \multicolumn{1}{|c|}{ Sig. } \\
\hline Between Groups & 1.630 & 10 & .163 & 3.090 & .003 \\
\hline Within Groups & 2.902 & 55 & .053 & & \\
\hline Total & 4.532 & 65 & & & \\
\hline
\end{tabular}

According to table 5 the significance was 0.003 with an $\mathrm{F}$ value of 3.090. The level of significance was lower than 0.05 and this means that financial services provided at NaiLab do show statistically significant relationship with performance of business ventures in NaiLab. Therefore this study accepts the alternative hypothesis and concludes that there is significant statistical relationship between financial services and performance of business ventures at NaiLab.

The findings shows strong positive association between performance of business ventures and access to financial services. This is a strong indication of the importance of access to timely finances for a business. The incubator manager should organise for a variety of financial services to incubatees business ventures to improve their performance level. Other researcher also have got supporting positions to the one held by this study for instance Lalkaka \& Abetti (1999) holds that for business ventures to be profitable, or even be simply self-sustainable, business incubators should carefully design a revenue generation model containing more than one source, or stream, of revenue.

\section{Conclusions and Recommendations}

The chapter provides a summary of findings, draws conclusion from the findings upon which recommendations are made, and then finally concludes with a suggestion for further research. This study aimed to examine the effect of business incubation services on performance of business ventures at NaiLab, Nairobi, Kenya. It was guided by four objectives

\subsection{Conclusion}

Physical infrastructure has major influence on performance of business ventures. Given positive correlation between physical infrastructure and performance of business ventures, it was concluded that provision of physical infrastructure like offices and rooms for start-up business in necessary at NaiLab to support performance of such business. This further suggests that management of NaiLab should enforce physical infrastructure services. However hypothesis test shows that physical infrastructure at the incubator may not be very necessary for incubates who can access the services of the incubator via the virtual platform especially technology oriented businesses.

Due to fact that relationship between networking services and business performance is positive and alternative hypothesis being accepted, It was concluded that NaiLab management should place more resources in cultivating useful networks for the benefit of incubates for instance connecting them to international customers and financiers who are ready to support them to enable them grow their young but highly promising business ventures.

The positive correlation between business management and performance of business ventures at NaiLab shows that provision of business management services like marketing, business plan writing are very essential for success of business venture in the business incubator and therefore should be enforced further. The management of incubator should also consider providing more marketing, counselling and book keeping services since most respondents were of the opinion that this specific services were not well provided for in the incubator.

The strong positive correlation between financial services and performance and the acceptance of the alternative hypothesis in the study of performance of business ventures at NaiLab is an indication that performance of business ventures hinges on their ability to access financial services as start-up capital and for daily running of business .Financial services like venture capital, Angel funds and share capital are very essential for faster expansion of profitable business ventures into bigger companies employing a large workforce.

\subsection{Recommendations}

Given positive correlation between physical infrastructure and performance of business ventures, the management of NaiLab should introduce a variety of physical infrastructure services to incubate while they are within the incubator. However for incubates who can access the incubator on the virtual platform may not need much of this service. Management of NaiLab should place more resources in cultivating useful networks for the benefit of incubates for instance connecting them to international customers and financiers who are ready to support them to enable them grow their young but highly promising business ventures. 


\section{International Journal of Science and Research (IJSR) \\ ISSN (Online): 2319-7064}

Index Copernicus Value (2013): 6.14 | Impact Factor (2015): 6.391

Management of NaiLab should ensure they provide a variety of business management services to incubatees. The findings revealed that the incubator should provide more business management services especially marketing, book keeping and counselling services which were not adequately provided. Based on positive correlation between financial services and performance of business ventures management of NaiLab should also provide a variety of financial services especially venture capital, Angel funds and share capital are very essential for faster expansion of venture business into bigger companies employing a large workforce. The management should also consider helping their incubatees access equity capital by the issue of shares to the general public to add to more sustainable financing of business ventures, they should also help in looking for investors who can buy these equity capital units when they are issued.

Suggestions for Further Studies: The current study was on effect of business incubator services on performance of business ventures at NaiLab. NaiLab specialises in technology oriented businesses hence the report has limited application within NaiLab incubator only. Hence Future studies should therefore widen the scope of study by carrying out a survey that includes a number of business incubators dealing in a number incubates with a variety of business ideas. This would improve wide application of report and findings across various incubators in the country.
[10]Collinson, S. and Gregson, G. (2003). Knowledge networks for new technology-based firms: an

international comparison of local entrepreneurship promotion. $R \& D$ Management Vol: 33, No: 2: 189208.

[11]Colombo, M. G. and Delmastro, M. (2002). How effective are technology incubators?: Evidence from Italy. Research Policy Vol: 31, No: 7: 11031122.

[12] Cooper, D.R. and Schindler, P.S. (2006). "Business Research Methods", 9th Ed, New York: Mc Graw-Hill Publications

[13] Goldmark, L. (1996). Business Development Services: A Framework for Analysis. Micro Enterprises Unit,InterAmerican Development Bank, Washington, DC. Working Paper No. MIC-101.

[14] Hackett, S. M. and Dilts, D. M. (2004b). A Systematic Review of Business Incubation Research. Journal of Technology Transfer Vol: 29, No: 1: 55-82.

[15]Hannon, P. (2003). A Conceptual Development Framework for Management \&Leadership learning in the UK incubator Sector. Education \& Training, 45 $(8 / 9), 449$

[16] Hurley, K. (2002). The First Incubator Business: Incubator Building. Economic Development Journal, Spring: 53-56.

[17] Ikiara, K. (1988). The Role of Government Institutions in Kenya?s Industrialization in Kenya. In Coughlin, P. \& Ikiara,G. K. Industrialization in Kenya: In Search of A Strategy. Nairobi: East African Educational Publishers Ltd.

[18] Khalil, M.A, Olafsen, E. (2010) Enabling innovative entrepreneurship through business incubation, World Bank Group

[19] Kombo, D. K., \& Tromp, D. A. (2006). Proposal and Thesis Writing:An Introduction. Nairobi, Nairobi county, Kenya: Paulines Publications Africa.

[20] Kothari, C.R. (2008). Research Methodology-Methods and Techniques. New Delhi:New Age International (P) Limited Publishers.

[21]Lalkaka, R. \& Abetti, P. (1999). Business Incubation \& Enterprise Support Systems in Restructuring Countries. Creativity \& Innovation Management, 8 (3): 197209.

[22] Lavrow, M. \& Sample, S. 2000. Business Incubation: Trend or Fad? Incubating the Start up Company to the Venture Capital Stage: Theory \& Practise. University of Ottawa. (Unpublished Master of Business Administration Thesis).

[23] Lesacova (2012), The Role of Business Incubators in Supporting the SME Start-up, Acta Polytechnica Hungarica, Vol. 9, No. 3:85-95

[24] Markley, D.M., \& McNamara, K.T. (1995). Economic and fiscal impacts of a business incubator. Economic Development Quarterly, 9(3), 273-278.

[25] Mbewana, P.N. (2006). The Key Success Factors for Business Incubation in South Africa: The Godisa Case Study. University of Pretoria. (Unpublished Master of Science Dissertation).

[26] McGrath, Rita Gunther. (1999). Falling Forward: Real Options Reasoning and Entrepreneurial Failure. The Academy of Management Review, 24(1), 1330.

[27] Meru, A. K., Struwig, M., (2011)An Evaluation Of The Entrepreneurs' Perception Of Business Incubation typology of incubation strategies from European research institutions. Journal of Business Venturing Vol: 20, No: 2: 183216. 
Services In Kenya, International Journal of Business Administration, Vol. 2, No. 4; P (112-121)

[28] Mian, S. (1996). Assessing value-added contributions of university technology business incubators to tenant firms. Research Policy, 25, 325-335.

[29] Molnar, L.A., Grimes, D.R., Edelstein, J. Pietro, R.D., Sherman, H., Adkins, D. \& Tornatzky, L. (1997). Business Incubation Works: The Results of the Impact of Incubator Investment Study. Athens: $\mathrm{OH}$ : National Business Incubation Association

[30] Mugenda, O., Mugenda, A. (2003) Research methods. Quantitative and Qualitative approaches. Nairobi. Africa Centre for technology studies

[31] Peters, L., Rice, M. and Sundararajan, M. (2004). The Role of Incubators in the Entrepreneurial Process. Journal of Technology Transfer Vol: 29, No: 1: 83 91.

[32] Remedios, R.K. B. \& Cornelius B. (2003). Cracks in the Egg: Improving Performance in Business Incubation Research. A paper for the Small Enterprise Association of Australia \& New Zeal\&, 16th Annual Conference, $28^{\text {th }}$ September to $1^{\text {st }}$ October, University of Ballarat. Ballarat.

[33] Rice, M., \& Abetti, P. (1992). Intervention mechanism utilized by business incubators to influence the critical success factors of new ventures: An exploratory study. Fontainebleau, France: Paper presented at Babson College Entrepreneurship Conference, INSEAD.

[34] Saunders, M., Lewis, \& M., Thornhill, A. (2012) Research methods for business students $\quad\left(6^{\text {th }} \mathrm{Ed}\right)$. Italy: Pearson education ltd.

[35] Sherman, H. (1999). Assessing the intervention effectiveness of business incubation programs on new business start-ups. Journal of Development Entrepreneurship, 4(2), 117-133.

[36] Sitkin, S. (1992). Learning through failure: The strategy of small losses. Research in Organizational Behaviour, 14, 231-266. Greenwich, CT: JAI Press.

[37] Smilor, R. W. (1987). Commercializing technology through new business incubators. Research Management Vol: 30, No: 5: 36-41.

[38] Voisey, P., Gornall, L., Jones, P. \& Thomas, B. (2006). The Measurement of Success in aBusiness Incubation Project. Journal of Small Business \& Enterprise Development, 13 (3),454-468. 